\title{
Assessment of Employee Using Simple Multi- Attribute Technique Exploiting Rank (SMARTER) and Behaviorally Anchor Rating Scale (BARS) Method
}

\author{
Heni Sulastri $\left.{ }^{1}{ }^{*}\right)$ \\ ${ }^{1}$ Informatics Department of Engineering Faculty, Siliwangi University \\ Tasikmalaya, Indonesia \\ email: ${ }^{1}$ henisulastri@unsil.ac.id
}

\begin{abstract}
Lecturers' active role as the spearhead of higher education has an essential role in improving higher education quality and sustainability. Therefore, assessing work behaviour is needed to measure how lecturers participate in achieving the vision and mission, quality improvement, and service guarantee to students and complementary documentation. This condition became the basis of research. They are implementing decision support systems with Simple Multi-Attribute Rating Technique Exploiting Ranges (SMARTER) and Graphic Rating Scale (GRS) to measure a lecturer's behaviour by using multiple criteria. With the SMARTER method and Behaviorally Anchor Rating Scale (BARS). By applying the impermeable BARS method, the work behaviour assessment process results in ease and accuracy that is more in line with the employees' behaviour being assessed. With the SMARTER approach, an assessment of employee work behaviour is produced, with $90 \%$ of alternatives used. The results are Good.
\end{abstract}

Keywords - Lecturer, BARS method, Method of SMARTER, Behavioral Assessment Work..

\section{INTRODUCTION}

Human resources have an essential role in the sustainability of an agency. Higher education is one of the educational institutions that have lecturers as human resources where lecturers' presence is one of the factors that is considered absolute. Lecturers are prominent supporters who interact directly with students. A lecturer is deemed qualified if he meets the qualifications and work behaviour and is competent in line with its vision and mission. Success is usually measured by the lecturer's level of success in teaching, the level of discipline in education, the ability to interact with students, and many other supporting factors [17].

In any organization, Behavior Assessment or the performance of each employee is an everyday activity. As stated by [7] which states that employee Behavior Assessment can be said to be effective if it includes the following two things, namely (1) the existence of a set of standards and (2) information communication (feedback). Dessler [10] "Effective appraisal also requires that the supervisor set performance standards. And it requires that the employee receives the training, feedback, and incentives required to eliminate performance deficiencies". Gary Dessler's opinion is increasingly confirmed that Conduct's assessment effectively requires a standard that has been I preset and feedback to prevent a decline. Likewise, in higher education institutions, whether in the form of universities, institutes, or colleges. In general, Job Performance Appraisal is a process by which organizations evaluate performance to improve performance [7].
Assessment of lecturer achievement aims to achieve the vision and mission of higher education institutions and accreditation needs [12].

Decision-making methods are used to be applied for job performance assessment. One of them is the Simple MultiAttribute Rating Technique Exploiting Ranges (SMARTER) method, which supports multi-criteria by giving weight to each criterion and sub-criteria that illustrates how critical the requirements are [2][10][13][18]. Each standard and sub-criteria, which are characteristics or several properties of items or items, will be presented by applying the Behaviorally Anchor Rating Scale (BARS) method [11][15].

This article proposes the combination of Simple MultiAttribute Rating Technique Exploiting Ranges (SMARTER) method and Behaviorally Anchor Rating Scale (BARS) to analyze the lecturer's performance in Siliwangi University.

\section{A. Job Performance Assessment}

Job Performance Appraisal is a formal system for assessing and evaluating the performance of an individual or team assignments used by industry, agencies, and organizations to generate feedback on performance following the standard set used [1][5]. Correct Job Performance Assessment will help relevant stakeholders and the employees or Human Resource Development division being assessed. The Job Performance Appraisal process consists of three stages: (1) defining the job, evaluating performance, and providing feedback [1]. 


\section{B. Decison Support System}

Decision support systems were first put forward in the early 1970 s by Michael S. Scott Morton. It was term Management Decision Systems to assist managers in making decisions on semi-structured problems, providing support for managers, increasing managers' decisions, speed computing, and productivity enhancement [10][14] Decision support systems are considered capable of solving problems and solving semi-structured issues [13]. A semistructured problem is a problem that includes several elements recognized by problem solvers. Decision-making correlates with the uncertainty of the results of the decisions taken to reduce risk factors.

The decision-making process consists of three phases, namely (1) the Intelligent step or the operation of tracking and detecting problems and identifying problems; (2) the design phase or the phase to understand the problem, reduce the risk and test the feasibility of the risk by conducting a process of finding, developing and analyzing alternative actions that can be taken; (3) Choice or a decision-making process based on the implemented alternative [3].

\section{Simple Multi-Attribute Rating Technique Exploiting Ranges (SMARTER)}

SMART is a multi-criteria decision-making method The multi-criteria decision-making technique is based on the theory that each alternative consists of several criteria that have value - value. Each standard has a weight that describer how important criteria are compared with other criteria [4]. The SMARTER method is developing the Simple Multi-Attribute Rating Technique ( SMART ) method introduced by Edward in 1977 [10]. In the SMARTER method, the Rank Order Centroid (ROC) weighting formula is used [6].

The equation for the SMARTER method can be seen in the following equation (1), where $U_{n}=$ Final Score, $W_{k}=$ Weighting from criteria $k, U_{n}\left(X_{n k}\right)=$ The utility value for the $\mathrm{k}$ criterion for the $\mathrm{k}$ alternative.

$$
U_{n}=\sum_{k=1}^{k} W_{k} U_{n}\left(X_{n k}\right)
$$

Calculation of utility value can use the following equation (2), where $U_{i}\left(a_{i}\right)$ is utility value for (i) criteria, $\mathrm{C}_{\mathrm{i}}$ is the value of the (i) criteria, $\mathrm{C}_{\min }$ is the minimum value of criteria, $\mathrm{C}_{\max }$ is the maximum value of criteria.

$$
U_{i}\left(a_{i}\right)=100 \% \times \frac{\left(C_{i}-C_{\min }\right)}{\left(C_{\text {maks }}-C_{\min }\right)}
$$

\section{Weighting Rank Order Centroid (ROC)}

The ROC technique's weighting works by giving weight to the criteria according to the ranking based on the priority level. The weighting of the ROC is generally formulated in equation (3), where $\mathrm{W}$ is the weight value of criteria, $\mathrm{k}$ is the number of criteria and $i$ is alternative value.

$$
W_{k}=\frac{1}{k} \sum_{i=1}^{k}\left(\frac{1}{i}\right)
$$

\section{E. Behavioural Anchor Rating Scale (BARS)}

The Behavioral Anchor Rating Scale (BARS) method is a performance appraisal method that combines work behaviour approaches with personal traits. Scaling is done between 5 to 10 vertical actions (Anchor) for each work indicator. Anchors are arranged from the highest value to the lowest cost. Anchors can be in the form of critical incidents obtained through job analysis, usually compiled by a team of Human Resources specialists, managers, and employees [8]. The stages in the Behavioral Anchor Rating Scale (BARS) method can be seen as follows:

a) Making a Critical Incident

b) Developing performance dimensions

c) Reallocating events

d) Making the scale of the incident

e) Developing the final tools

The BARS method has several positive values that are more accurate because the experts have developed the BARS in the HRD devising. HRD has more precise standards, can generate feedback, systematically critical group events (Anchors) into five to ten independent dimensions, and has consistent properties [8][11] [15]

\section{F. Related Research}

Several studies on the SMARTER and BARS methods have been carried out to optimize of decision-maker. Alfa Saleh et al. in 2018 determine the selection of laboratory assistants by applying the Simple Multi-Attribute Rating Technique Exploiting Ranges (SMARTER) method by applying six criteria and weighting accordingly [10]. With assessment priorities and produce research results that the technique used can provide useful recommendations. Other related research involves the Simple Multi-Attribute Rating Technique Exploiting Ranges (SMARTER) method to determine life insurance product recommendations to customers. Research results show that the SMARTER method is optimal and feasible as alternative decision support by Haryanti et.all in 2016 [6]. This research is also strengthened by other research that applies the SMARTER method in selecting and evaluating suppliers of Brazil's construction industry. The SMARTER method is considered efficient in selecting suppliers, providing supplier recommendations in the form of ranking by prioritizing the quality and price offered by each supplier by Schram and Danielle in 2012 [9]

Related research regarding the BARS method includes a study conducted by Michelle Martin-Raugh, et al. 2016 [8] regarding the application to evaluate teaching practice with the results of her research stating that the BARS method is preferred the assessment process than the FFT method. Other research related to BARS, such as that conducted by Donald P Schwab et al. in 2006 [11], measured BARS with the following three characteristics: Leniency Effect, Independent Dimension, and Reliability results showing that the BARS method still needs further research.

\section{RESEARCH METHODOLOGY}

The stages in the research are carried out as in the following figure: 


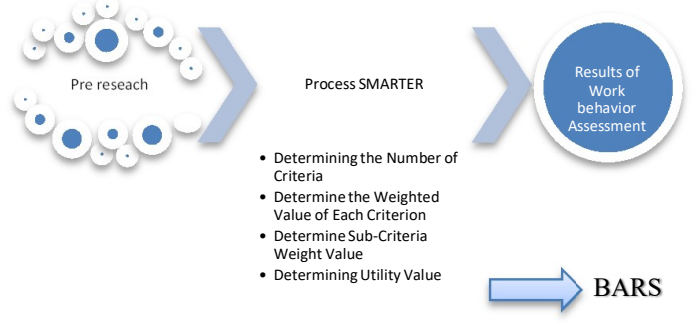

Figure 1. Research Diagram

This research is divided into three main stages, namely (1) Pre research, (2) process SMARTER, (3) behaviour Assessment System.

\section{A. Pre Research}

The pre-research begins with direct and indirect observations of the lecturer job performance assessment in one of the tertiary institutions to find an overview of the Lecturer Job Performance Assessment process. The resulting observations' results are continued by identifying the problem to produce a problem formulation and limitation. A literature study is conducted to provide research guidance in finding solutions to solve the problems formulated.

\section{B. Process SMARTER}

SMARTER method that is carried out consists of the following stages:

a) Determining the Number of Criteria

The Lecturer Work Behavior Assessment Process that is carried out refers to Law No. 5 of 2014, Articles 75-78 of ASN, and Government Regulation No.46 of 2011 concerning Assessment of Civil Servant Work Performance. The criteria used are as follows:

Table 1. Criteria
\begin{tabular}{|l|l|l|}
\hline No. & Criteria & The Type of Criteria \\
\hline 1 & Service Orientation & Categorical \\
\hline 2 & Integrity & Categorical \\
\hline 3 & Commitment & Categorical \\
\hline 4 & Discipline & Categorical \\
\hline 5 & Cooperation & Categorical \\
\hline 6 & Leadership & Categorical \\
\hline
\end{tabular}

b) Determine the Weight Value of Each Criterion

Each criterion's weight and priority levels are determined based on the priority level using equation 3, namely Rank Order Centroid (ROC) weighting.

Table 2 Weighted Criteria Value

\begin{tabular}{|l|l|l|l|}
\hline No. & Criteria & $\begin{array}{l}\text { Priority } \\
\text { Level }\end{array}$ & Weighted Value \\
\hline 1 & Service Orientation & 1 & 0.408 \\
\hline 2 & Integrity & 2 & 0.242 \\
\hline 3 & Commitment & 3 & 0.158 \\
\hline 4 & Discipline & 4 & 0.103 \\
\hline 5 & Cooperation & 5 & 0.061 \\
\hline 6 & Leadership & 6 & 0.028 \\
\hline
\end{tabular}

Based on table 2 above, Service Orientation has the highest weight value according to the priority level enforced on the grounds that lecturers have priority to provide services both internally and externally. c) Weight Value of Sub Criteria

Table 3. Sub-criteria weight values

\begin{tabular}{|c|c|c|c|}
\hline No. & Criteria & Sub-criteria & Weight \\
\hline 1 & Service Orientation & $\begin{array}{l}91 \leq \text { score } \leq 100 \\
76 \leq \text { score } \leq 90 \\
61 \leq \text { score } \leq 75 \\
51 \leq \text { score } \leq 60 \\
\text { Under } 50\end{array}$ & $\begin{array}{l}0.457 \\
0.257 \\
0.157 \\
0.090 \\
0.040\end{array}$ \\
\hline 2 & Integrity & $\begin{array}{l}91 \leq \text { score } \leq 100 \\
76 \leq \text { score } \leq 90 \\
61 \leq \text { score } \leq 75 \\
51 \leq \text { score } \leq 60 \\
\text { Under } 50\end{array}$ & $\begin{array}{l}0.457 \\
0.257 \\
0.157 \\
0.090 \\
0.040\end{array}$ \\
\hline 3 & Commitment & $\begin{array}{l}91 \leq \text { score } \leq 100 \\
76 \leq \text { score } \leq 90 \\
61 \leq \text { score } \leq 75 \\
51 \leq \text { score } \leq 60 \\
\text { Under } 50\end{array}$ & $\begin{array}{l}0.457 \\
0.257 \\
0.157 \\
0.090 \\
0.040 \\
\end{array}$ \\
\hline 4 & Discipline & $\begin{array}{l}91 \leq \text { score } \leq 100 \\
76 \leq \text { score } \leq 90 \\
61 \leq \text { score } \leq 75 \\
51 \leq \text { score } \leq 60 \\
\text { Under } 50\end{array}$ & $\begin{array}{l}0.457 \\
0.257 \\
0.157 \\
0.090 \\
0.040\end{array}$ \\
\hline 5 & Cooperation & $\begin{array}{l}91 \leq \text { score } \leq 100 \\
76 \leq \text { score } \leq 90 \\
61 \leq \text { score } \leq 75 \\
51 \leq \text { score } \leq 60 \\
\text { Under } 50\end{array}$ & $\begin{array}{l}0.457 \\
0.257 \\
0.157 \\
0.090 \\
0.040\end{array}$ \\
\hline 6 & Leadership & $\begin{array}{l}91 \leq \text { score } \leq 100 \\
76 \leq \text { score } \leq 90 \\
61 \leq \text { score } \leq 75 \\
51 \leq \text { score } \leq 60 \\
\text { Under } 50\end{array}$ & $\begin{array}{l}0.457 \\
0.257 \\
0.157 \\
0.090 \\
0.040\end{array}$ \\
\hline
\end{tabular}

Based on table 3 above, the weight values for each subcriterion are categorized based on the achievement number $91 \leq$ core $\leq 100$ for the title Very Good, $76 \leq$ score $\leq 90$ for the title Good, $61 \leq$ scores $\leq 75$ for the term Enough, $51 \leq$ scores $\leq 60$ for Less, and Under 50 for Bad designations.

While in Table 4 shows the formulation of assessment using the bars method, where the evaluation has sub-criteria.

Table 4. Formulation of Assessment using the BARS Method

\begin{tabular}{|c|c|c|}
\hline Indicator & Rating & Anchor \\
\hline \multirow{5}{*}{$\begin{array}{l}\text { Service } \\
\text { Orientation }\end{array}$} & $\begin{array}{l}\text { Very } \\
\text { good }\end{array}$ & $\begin{array}{l}\text { Always be able to complete service tasks } \\
\text { and possible with a polite and very } \\
\text { satisfying attitude for both internal and } \\
\text { external service to the organization. }\end{array}$ \\
\hline & Good & $\begin{array}{l}\text { In general, can complete service tasks well } \\
\text { with a polite and satisfying attitude for } \\
\text { both internal and external service to the } \\
\text { organization }\end{array}$ \\
\hline & Enough & $\begin{array}{l}\text { Sometimes he can complete service tasks } \\
\text { quite well, and the attitude is quite polite } \\
\text { and satisfying enough for both internal and } \\
\text { external services to the organization. }\end{array}$ \\
\hline & less & $\begin{array}{l}\text { Not complete service tasks correctly and } \\
\text { attitude less polite and unsatisfactory for } \\
\text { both internal and external services. }\end{array}$ \\
\hline & Bad & $\begin{array}{l}\text { Not completing the task with good service } \\
\text { and rude attitude and unsatisfactory both } \\
\text { for the internal and external service } \\
\text { organization. }\end{array}$ \\
\hline \multirow{3}{*}{ Integrity } & $\begin{array}{l}\text { Very } \\
\text { good }\end{array}$ & $\begin{array}{l}\text { Always in carrying out duties, to be honest, } \\
\text { sincere, and never abuse one's authority } \\
\text { and dare to bear the risk of the actions } \\
\text { he/she does. }\end{array}$ \\
\hline & Good & $\begin{array}{l}\text { In general, carrying out the tasks honestly, } \\
\text { sincere, and never to abuse the authority } \\
\text { and responsibility to the actions taken. }\end{array}$ \\
\hline & Enough & $\begin{array}{l}\text { Occasionally / sometimes, in carrying out } \\
\text { his duties, he is quite honest, entirely } \\
\text { sincere. Sometimes he misses the authority }\end{array}$ \\
\hline
\end{tabular}




\begin{tabular}{|c|c|c|c|c|c|}
\hline & & $\begin{array}{l}\text { and is brave enough to bear the risk of his } \\
\text { actions. }\end{array}$ & & & $\begin{array}{l}\text { responsibility, adheres to the provisions of } \\
\text { working hours and is able to properly store }\end{array}$ \\
\hline & \multirow[b]{2}{*}{ less } & \multirow{2}{*}{$\begin{array}{l}\text { Lack of honesty, lack of sincerity, carrying } \\
\text { out their duties, and often misuse their } \\
\text { authority, but they are not brave enough to } \\
\text { bear the risk of their actions. }\end{array}$} & & & $\begin{array}{l}\text { and / or maintain state property entrusted } \\
\text { to him. }\end{array}$ \\
\hline & & & & \multirow{3}{*}{ Enough } & \multirow{3}{*}{$\begin{array}{l}\text { Sometimes he obeys the prevailing laws } \\
\text { and / or official regulations with a sense of } \\
\text { responsibility, regards the provisions of } \\
\text { working hours and is sufficiently capable } \\
\text { of storing and / or maintaining state-owned } \\
\text { goods entrusted to him quite well, and not } \\
\text { entering or being late for work. and go } \\
\text { home sooner than the stipulated working } \\
\text { hours without valid reasons for } 5 \text { (five) to } \\
15 \text { (fifteen) working days. }\end{array}$} \\
\hline & $\mathrm{Bad}$ & $\begin{array}{l}\text { No, dishonest, sincere, in performing the } \\
\text { task, and always abusing his authority and } \\
\text { did not dare to risk their actions. }\end{array}$ & & & \\
\hline \multirow{12}{*}{ Commitments } & \multirow[b]{2}{*}{$\begin{array}{l}\text { Very } \\
\text { good }\end{array}$} & \multirow{2}{*}{$\begin{array}{l}\text { Always work diligently to uphold the } \\
\text { ideology of the state Pancasila, 1945 } \\
\text { Constitution Of The Republic Of } \\
\text { Indonesia, Unitary State of the Republic of } \\
\text { Indonesia, this singular diversity and } \\
\text { government plans with the aim to be able } \\
\text { to carry out its duties and prioritize the } \\
\text { interests of the government rather than } \\
\text { personal interests and / or groups in } \\
\text { accordance with duties, functions and his } \\
\text { responsibilities as a state apparatus to } \\
\text { workplace organizations }\end{array}$} & & & \\
\hline & & & & less & $\begin{array}{l}\text { Lack of obeying the prevailing statutory } \\
\text { regulations and/or official service } \\
\text { regulations with a sense of lack of } \\
\text { responsibility, obeying working hours } \\
\text { regulations and being unable to store and / } \\
\text { or maintain state property entrusted to } \\
\text { them poorly, and not entering or being late }\end{array}$ \\
\hline & & $\begin{array}{l}\text { Generally tried earnestly to uphold the } \\
\text { ideology of the state Pancasila, 1945 } \\
\text { Constitution Of The Republic Of } \\
\text { Indonesia, Unitary State of the Republic of }\end{array}$ & & & $\begin{array}{l}\text { for work and go home sooner than the } \\
\text { stipulated working hours without a valid } \\
\text { reason for } 16 \text { (sixteen) to } 30 \text { (thirty) } \\
\text { working days. }\end{array}$ \\
\hline & Good & $\begin{array}{l}\text { Indonesia, this singular diversity and } \\
\text { government plans with the aim to be able } \\
\text { to carry out its duties and prioritize the } \\
\text { interests of the government rather than } \\
\text { personal interests and / or groups in } \\
\text { accordance with duties, functions and his } \\
\text { responsibilities as a state apparatus to } \\
\text { workplace organizations } \\
\text { Sometime trving earnestly to uphold the }\end{array}$ & & $\mathrm{Bad}$ & $\begin{array}{l}\text { Never obeyed the rules of the Law and / or } \\
\text { the rules of business that occur with a sense } \\
\text { of irresponsibility, comply with the } \\
\text { working hours and not be able to store and } \\
\text { / or maintain state-owned goods entrusted } \\
\text { to him in a good way, and do not enter or } \\
\text { be late for work and return from work } \\
\text { hours without a valid reason for more than } \\
31 \text { working days. }\end{array}$ \\
\hline & \multirow[t]{2}{*}{ Enough } & \multirow{2}{*}{$\begin{array}{l}\text { Sometime trying earnestly to uphold the } \\
\text { ideology of the state Pancasila, 1945 } \\
\text { Constitution Of The Republic Of } \\
\text { Indonesia, Unitary State of the Republic of } \\
\text { Indonesia, this singular diversity and } \\
\text { government plans with the aim to be able } \\
\text { to carry out its duties and prioritize the } \\
\text { interests of the government rather than } \\
\text { personal interests and / or groups in } \\
\text { accordance with duties, functions and his } \\
\text { responsibilities as a state apparatus to } \\
\text { workplace organizations }\end{array}$} & \multirow{7}{*}{ Cooperation } & $\begin{array}{l}\text { Very } \\
\text { good }\end{array}$ & $\begin{array}{l}31 \text { working days. } \\
\text { Always able to cooperate with colleagues, } \\
\text { superiors, subordinates both inside and } \\
\text { outside the organization and respect and } \\
\text { accept the opinions of others, willing to } \\
\text { accept decisions taken legally which have } \\
\text { become joint decisions. }\end{array}$ \\
\hline & & & & Good & $\begin{array}{l}\text { In general, they are able to cooperate with } \\
\text { colleagues, superiors, subordinates both } \\
\text { inside and outside the organization and } \\
\text { respect and accept other people's opinions, } \\
\text { are willing to accept decisions made }\end{array}$ \\
\hline & \multirow{3}{*}{ less } & \multirow{3}{*}{$\begin{array}{l}\text { Less trying in earnestly to uphold the } \\
\text { ideology of the state Pancasila, 1945 } \\
\text { Constitution Of The Republic Of } \\
\text { Indonesia, Unitary State of the Republic of } \\
\text { Indonesia, this singular diversity and } \\
\text { government plans with the aim to be able } \\
\text { to carry out its duties and prioritize the } \\
\text { interests of the government rather than } \\
\text { personal interests and / or groups in } \\
\text { accordance with duties, functions and his } \\
\text { responsibilities as a state apparatus to } \\
\text { workplace organizations }\end{array}$} & & & legally which have become joint decisions. \\
\hline & & & & Enough & $\begin{array}{l}\text { Sometimes able to work together with } \\
\text { colleagues, superiors, subordinates both } \\
\text { inside and outside the organization and } \\
\text { sometimes respect and accept the opinions } \\
\text { of others, sometimes willing to accept } \\
\text { decisions taken legally which have become } \\
\text { joint decisions. }\end{array}$ \\
\hline & & & & \multirow[t]{2}{*}{ less } & \multirow{2}{*}{$\begin{array}{l}\text { Less able to cooperate with colleagues, } \\
\text { superiors, subordinates both inside and } \\
\text { outside the organization and less respect } \\
\text { and acceptance of other people's opinions, } \\
\text { less willing to accept decisions made } \\
\text { legally which have become joint decisions. }\end{array}$} \\
\hline & \multirow{3}{*}{ Bad } & \multirow{3}{*}{$\begin{array}{l}\text { Never tried earnestly to uphold the } \\
\text { ideology of the state Pancasila, 1945 } \\
\text { Constitution Of The Republic Of } \\
\text { Indonesia, Unitary State of the Republic of } \\
\text { Indonesia, this singular diversity and } \\
\text { government plans with the aim to be able } \\
\text { to carry out its duties and prioritize the } \\
\text { interests of the government rather than } \\
\text { personal interests and / or groups in } \\
\text { accordance with duties, functions and his } \\
\text { responsibilities as a state apparatus to } \\
\text { workplace organizations }\end{array}$} & & & \\
\hline & & & & $\mathrm{Bad}$ & $\begin{array}{l}\text { Have never been able to cooperate with } \\
\text { colleagues, superiors, subordinates both } \\
\text { inside and outside the organization and do } \\
\text { not respect and accept other people's } \\
\text { opinions, are not willing to take decisions } \\
\text { made legally which have become joint } \\
\text { decisions. }\end{array}$ \\
\hline & & & \multirow{4}{*}{ Leadership } & \multirow[b]{2}{*}{$\begin{array}{l}\text { Very } \\
\text { good }\end{array}$} & \multirow{2}{*}{$\begin{array}{l}\text { Always act firmly and impartially, provide } \\
\text { a good example, the ability to move work } \\
\text { teams to achieve high performance, } \\
\text { capable of uplifting and moving } \\
\text { subordinates in carrying out the task and } \\
\text { able to make decisions quickly and } \\
\text { accurately. }\end{array}$} \\
\hline \multirow{3}{*}{ Discipline } & \multirow[t]{2}{*}{$\begin{array}{l}\text { Very } \\
\text { good }\end{array}$} & \multirow{2}{*}{$\begin{array}{l}\text { Always comply with laws and regulations } \\
\text { and / or official service regulations with a } \\
\text { sense of responsibility and still comply } \\
\text { with the provisions of working hours and } \\
\text { be able to properly store and / or maintain } \\
\text { state property entrusted to them }\end{array}$} & & & \\
\hline & & & & \multirow{2}{*}{ Good } & \multirow{2}{*}{$\begin{array}{l}\text { In general, act decisively and impartially, } \\
\text { provide good role models, the ability to } \\
\text { mobilize the work team to achieve high } \\
\text { performance, be able to inspire and move }\end{array}$} \\
\hline & Good & $\begin{array}{l}\text { In general, he obeys the prevailing laws } \\
\text { and / or official regulations with a sense of }\end{array}$ & & & \\
\hline
\end{tabular}

JISA (Jurnal Informatika dan Sains) (e-ISSN: 2614-8404) is published by Program Studi Teknik Informatika, Universitas Trilogi under Creative Commons Attribution-ShareAlike 4.0 International License. 


\begin{tabular}{|l|l|l|}
\hline \multirow{5}{*}{ Enough } & $\begin{array}{l}\text { subordinates in carrying out their duties } \\
\text { and be able to make decisions quickly and } \\
\text { accurately. }\end{array}$ \\
\cline { 2 - 3 } & $\begin{array}{l}\text { Sometimes acting decisively and } \\
\text { impartially, setting an example, being } \\
\text { sufficiently capable of mobilizing the work } \\
\text { team to achieve high performance, and } \\
\text { enough capable of arousing enthusiasm } \\
\text { and mobilizing subordinates in carrying } \\
\text { out their duties and capable of making } \\
\text { decisions quickly and accurately }\end{array}$ \\
\hline \multirow{5}{*}{ less } & $\begin{array}{l}\text { Lack of acting decisively and sometimes } \\
\text { taking sides, less able to provide good role } \\
\text { models, less able to mobilize the work } \\
\text { team to achieve high performance, and less } \\
\text { able to inspire enthusiasm and mobilize } \\
\text { subordinates in carrying out tasks and less } \\
\text { able to make decisions quickly and } \\
\text { accurately }\end{array}$ \\
\hline Bad & $\begin{array}{l}\text { Not been able to act firmly and impartially, } \\
\text { not a good example, not be able to } \\
\text { mobilize work teams to achieve high } \\
\text { performance, unable to inspire the spirit } \\
\text { and stir subordinates in carrying out their } \\
\text { duties and are not able to make decisions } \\
\text { quickly and accurately. }\end{array}$ \\
\hline
\end{tabular}

d) Determining the Value of Utilities

By applying equation 2 (two), we can get the value of Utility.

e) Work Behavior Assessment System

The final result of this lecturer work behaviour assessment can produce a ranking based on the alternatives that have been used. Ranking results can be input for superiors in making decisions.

\section{RESULT AND DISCUSSION}

In this study, ten lecturers' data were used to carry out work performance assessments including data on the value of Service Orientation (C1), Integrity (C2), Commitment (C3), Discipline (C4), Cooperation (C5) and Leadership (C6).

The data used from lecturers who have carried out work performance assessments for 2019 even semester, where ten lecturer data will be used as an alternative in testing the SMARTER and BARS methods. The following ten lecturer data can be seen in table 5 :

Table 5. Sub-criteria weights for each alternative.
\begin{tabular}{|l|l|l|l|l|l|l|}
\hline $\mathbf{A}$ & C1 & C2 & C3 & C4 & C5 & C6 \\
\hline 1 & Good & $\begin{array}{l}\text { Very } \\
\text { good }\end{array}$ & Very good & Good & Good & Very good \\
\hline 2 & Very good & Good & Good & Good & Good & Good \\
\hline 3 & Good & Good & Good & Very good & Good & Good \\
\hline 4 & Good & Good & Good & Good & Very good & Good \\
\hline 5 & Good & $\begin{array}{l}\text { Very } \\
\text { good }\end{array}$ & Good & Good & Good & Good \\
\hline 6 & Good & Good & Very good & Very good & Good & Good \\
\hline 7 & Very good & Good & Good & Good & Good & Good \\
\hline 8 & Very good & Good & Good & Good & Good & Very good \\
\hline 9 & Very good & $\begin{array}{l}\text { Very } \\
\text { good }\end{array}$ & Good & Good & Good & Good \\
\hline 10 & Good & Good & Very good & Good & Very good & Good \\
\hline
\end{tabular}

normalization results for all alternatives can be seen in Table 6

Table 6. The results of the normalization of the criteria values

\begin{tabular}{|l|l|l|l|l|l|l|}
\hline $\mathrm{A}$ & $\mathrm{C} 1$ & $\mathrm{C} 2$ & $\mathrm{C} 3$ & $\mathrm{C} 4$ & $\mathrm{C} 5$ & $\mathrm{C} 6$ \\
\hline 1 & 0.257 & 0.457 & 0.457 & 0.257 & 0.257 & 0.457 \\
\hline 2 & 0.457 & 0.257 & 0.257 & 0.257 & 0.257 & 0.257 \\
\hline 3 & 0.257 & 0.257 & 0.257 & 0.457 & 0.257 & 0.257 \\
\hline 4 & 0.257 & 0.257 & 0.257 & 0.257 & 0.457 & 0.257 \\
\hline 5 & 0.257 & 0.457 & 0.257 & 0.257 & 0.257 & 0.257 \\
\hline 6 & 0.257 & 0.257 & 0.457 & 0.457 & 0.257 & 0.257 \\
\hline 7 & 0.457 & 0.257 & 0.257 & 0.257 & 0.257 & 0.257 \\
\hline 8 & 0.457 & 0.257 & 0.257 & 0.257 & 0.257 & 0.457 \\
\hline 9 & 0.457 & 0.457 & 0.257 & 0.257 & 0.257 & 0.257 \\
\hline 10 & 0.257 & 0.257 & 0.457 & 0.257 & 0.457 & 0.257 \\
\hline
\end{tabular}

The values in table 6 above are obtained from the results of the initial value transformation of the criteria with the weight value of each sub-criteria calculated using ROC weighting. Then the normalized result value will be converted into a utility value using equation 2 . The following utility values for each criterion and alternative are shown in table 7.

Table 7. Value of Utility

\begin{tabular}{|l|l|l|l|l|l|l|}
\hline $\mathbf{A}$ & $\mathbf{C 1}$ & $\mathbf{C 2}$ & $\mathbf{C 3}$ & $\mathbf{C 4}$ & $\mathbf{C 5}$ & $\mathbf{C 6}$ \\
\hline 1 & 0,520 & 1 & 1 & 0,520 & 0,520 & 1 \\
\hline 2 & 1 & 0,520 & 0,520 & 0,520 & 0,520 & 0,520 \\
\hline 3 & 0,520 & 0,520 & 0,520 & 1 & 0,520 & 0,520 \\
\hline 4 & 0,520 & 0,520 & 0,520 & 0,520 & 1 & 0,520 \\
\hline 5 & 0,520 & 1 & 0,520 & 0,520 & 0,520 & 0,520 \\
\hline 6 & 0,520 & 0,520 & 1 & 1 & 0,520 & 0,520 \\
\hline 7 & 1 & 0,520 & 0,520 & 0,520 & 0,520 & 0,520 \\
\hline 8 & 1 & 0,520 & 0,520 & 0,520 & 0,520 & 1 \\
\hline 9 & 1 & 1 & 0,520 & 0,520 & 0,520 & 0,520 \\
\hline 10 & 0,520 & 0,520 & 1 & 0,520 & 1 & 0,520 \\
\hline
\end{tabular}

Based on the utility value generated, the next step is to determine the final value. Equation 1 is used to calculate the final amount (NA) in the Smarter method, as can be seen in table 8 to table 10 below.

Table 8. Final scores using the SMARTER method

\begin{tabular}{|l|l|l|l|l|l|l|l|}
\hline A & C1 & C2 & C3 & C4 & C5 & C6 & NA \\
\hline 1 & 0,067 & 0,129 & 0,129 & 0,067 & 0,067 & 0,028 & 0,487 \\
\hline 2 & 0,129 & 0,067 & 0,067 & 0,067 & 0,067 & 0,015 & 0,412 \\
\hline 3 & 0,067 & 0,067 & 0,067 & 0,129 & 0,067 & 0,015 & 0,412 \\
\hline 4 & 0,067 & 0,067 & 0,067 & 0,067 & 0,129 & 0,015 & 0,412 \\
\hline 5 & 0,067 & 0,129 & 0,067 & 0,067 & 0,067 & 0,015 & 0,412 \\
\hline 6 & 0,067 & 0,067 & 0,129 & 0,129 & 0,067 & 0,015 & 0,474 \\
\hline 7 & 0,129 & 0,067 & 0,067 & 0,067 & 0,067 & 0,015 & 0,412 \\
\hline 8 & 0,129 & 0,067 & 0,067 & 0,067 & 0,067 & 0,028 & 0,426 \\
\hline 9 & 0,129 & 0,129 & 0,067 & 0,067 & 0,067 & 0,015 & 0,474 \\
\hline 10 & 0,067 & 0,067 & 0,129 & 0,067 & 0,129 & 0,015 & 0,474 \\
\hline
\end{tabular}

Table 9. Assessment of Job Performance with the SMARTER Method

\begin{tabular}{|l|l|l|l|l|l|l|l|l|l|}
\hline $\mathbf{A}$ & $\mathbf{C 1}$ & $\mathbf{C 2}$ & $\mathbf{C 3}$ & $\mathbf{C 4}$ & $\mathbf{C 5}$ & $\mathbf{C 6}$ & $\mathbf{N A}$ & \% & $\mathbf{R}$ \\
\hline 1 & 0,067 & 0,129 & 0,129 & 0,067 & 0,067 & 0,028 & 0,487 & 48.7 & \\
\hline 6 & 0,067 & 0,067 & 0,129 & 0,129 & 0,067 & 0,015 & 0,474 & 47.4 & \\
\hline 9 & 0,129 & 0,129 & 0,067 & 0,067 & 0,067 & 0,015 & 0,474 & 47.4 & 3 \\
\hline 10 & 0,067 & 0,067 & 0,129 & 0,067 & 0,129 & 0,015 & 0,474 & 47.4 & \\
\hline 8 & 0,129 & 0,067 & 0,067 & 0,067 & 0,067 & 0,028 & 0,426 & 42.6 & 5 \\
\hline 2 & 0,129 & 0,067 & 0,067 & 0,067 & 0,067 & 0,015 & 0,412 & 41.2 & 5 \\
\hline 3 & 0,067 & 0,067 & 0,067 & 0,129 & 0,067 & 0,015 & 0,412 & 41.2 & \\
\hline 4 & 0,067 & 0,067 & 0,067 & 0,067 & 0,129 & 0,015 & 0,412 & 41.2 & 3 \\
\hline 5 & 0,067 & 0,129 & 0,067 & 0,067 & 0,067 & 0,015 & 0,412 & 41.2 & \\
\hline 7 & 0,129 & 0,067 & 0,067 & 0,067 & 0,067 & 0,015 & 0,412 & 41.2 & 0 \\
\hline
\end{tabular}

based on table 5 , the next process is to normalize the criteria values based on the weights in Table 3 .

JISA (Jurnal Informatika dan Sains) (e-ISSN: 2614-8404) is published by Program Studi Teknik Informatika, Universitas Trilogi under Creative Commons Attribution-ShareAlike 4.0 International License. 
Table 10. Assessment of Job Performance with the SMARTER Method

\begin{tabular}{|c|c|c|c|c|c|c|c|c|}
\hline $\mathbf{A}$ & C1 & $\mathrm{C2}$ & $\mathrm{C3}$ & $\mathrm{C4}$ & C5 & C6 & Aktul & $\begin{array}{l}\text { SMA } \\
\text { RTE } \\
\text { R } \\
\end{array}$ \\
\hline 1 & Good & $\begin{array}{l}\text { Very } \\
\text { good }\end{array}$ & $\begin{array}{l}\text { Very } \\
\text { good }\end{array}$ & Good & Good & $\begin{array}{l}\text { Very } \\
\text { good }\end{array}$ & Good & Enaugh \\
\hline 2 & $\begin{array}{l}\text { Very } \\
\text { good }\end{array}$ & Good & Good & Good & Good & Good & Good & Enaugh \\
\hline 3 & Good & Good & Good & $\begin{array}{l}\text { Very } \\
\text { good }\end{array}$ & Good & Good & Good & $\begin{array}{l}\text { Mediu } \\
\mathrm{m}\end{array}$ \\
\hline 4 & Good & Good & Good & Good & $\begin{array}{l}\text { Very } \\
\text { good }\end{array}$ & Good & Good & $\begin{array}{l}\text { Mediu } \\
\mathrm{m}\end{array}$ \\
\hline 5 & Good & $\begin{array}{l}\text { Very } \\
\text { good }\end{array}$ & Good & Good & Good & Good & Good & Enaugh \\
\hline 6 & Good & Good & $\begin{array}{l}\text { Very } \\
\text { good }\end{array}$ & $\begin{array}{l}\text { Very } \\
\text { good }\end{array}$ & Good & Good & Good & Enaugh \\
\hline 7 & $\begin{array}{l}\text { Very } \\
\text { good }\end{array}$ & Good & Good & Good & Good & Good & Good & Enaugh \\
\hline 8 & $\begin{array}{l}\text { Very } \\
\text { good }\end{array}$ & Good & Good & Good & Good & $\begin{array}{l}\text { Very } \\
\text { good }\end{array}$ & Good & Enaugh \\
\hline 9 & $\begin{array}{l}\text { Very } \\
\text { good }\end{array}$ & $\begin{array}{l}\text { Very } \\
\text { good }\end{array}$ & Good & Good & Good & Good & Good & Good \\
\hline $\begin{array}{l}1 \\
0\end{array}$ & Good & Good & $\begin{array}{l}\text { Very } \\
\text { good }\end{array}$ & Good & $\begin{array}{l}\text { Very } \\
\text { good }\end{array}$ & Good & Good & Enaugh \\
\hline
\end{tabular}

Based on table 8 , which shows the final value of the calculation using the SMARTER method, a ranking $(\mathrm{R})$ of the highest alternative final value to the lowest alternative value can be formed as in table 9 .

The results of the ranking in table 9 can be used as a test by comparing the results of the decision holders' actual decisions with the results of applying the SMARTER method in table 10 .

Based on the results of the comparison table 10 with the application of the method to the actual assessment SMARTER able to provide alternative recommendations for the decision if the decision-making process based on the weighted criteria or the level of interest among different criteria.

\section{CONCLUSION}

Work Behavior Assessment carried out by applying the Simple Multi-Attribute Rating Technique Exploiting Ranges (SMARTER) and Behaviorally Anchor Rating Scale (BARS) methods. The result shows that the work behaviour appraisal process requires measurable and transparent standards, is objective and produces feedback on employee work behaviour achievements.

By applying these two methods, a more objective assessment of work behaviour is produced by applying a behavioural assessment with several anchors used, as well as producing behavioural assessment feedback in the form of a final value that becomes a reference in decision making for management [17].

\section{REFERENCES}

[1] Dessler, G. (2013). Human Resource Management, 13th Edition. London: Pearson Prentice Hall Inc.

[2] Dewi, M. A., Murad, D. F., \& Rosdiana. (2019). Implementation Of The Smart Models For Application Development Employee Performance Appraisal. International Conference on Sustainable Information Engineering and Technology (SIET) (pp. 364-269). Lombok, Indonesia: IEEE.

[3] Edward, W., \& F.Hutton, B. (1994). Edwards, W. And Barron, F.H. Smarts And Smarter: Improved Simple Methods For Multi Attribute Utility Measurement, Organizational Behaviour And Human
Decision Process, 1994. Organizational Behavior and Human Decision Processes, 306-325.

[4] Evita, S., Zusnita Muizu, W., \& Atmojo, R. (2017). Employee Performance Appraisal Using Behaviorally Anchor Rating Scale Methods And Management By Objectives (Case Study at PT Qwords Company International). Pebkis Jurnal, 18-32.

[5] Han, J., \& Kamber, M. (2000). Data Mining : Concepts and Techniques. San Fransisco: Morgan Kaufmann Publishers.

[6] Haryanti, D., Nasution, H., \& Sukamto, A. S. (2016). Dwi Haryanti, Helfi Nasution, Anggi Srimurdianti S. Decision Support System for Admission of Bidikmisi Full Scholarship Replacement Students at Tanjungpura University by Applying the Smarter Method. Journal of Information Technology and Systems, 1-7.

[7] Hollenbeck, J., Noe, R., Wright, P., \& Gerhart, B. (2012). Human Resource Management. In J. Hollenbeck, R. Noe, P. Wright, \& B. Gerhart, Human Resource Management Gaining Competitive Advantage. Boston: McGraw-Hill Education.

[8] Martin-Raugh, M., Tannenbaum, R., Tocci, C., \& Reese, C. (2016) Behaviorally anchored rating scales: An application for evaluating. Teaching and Teacher Education, 414-419.

[9] Morais, D., \& Schramm, F. (2012). Decision Support Model for Selecting and Evaluating Suppliers in the Construction Industry. Pesquisa Operacional, 643-662.

[10] Saleh, A., Puspita, K., Sanjaya, A., Daifiria, \& Giovani. (2018). Implementation of Equal Width Interval Discretization on SMARTER Method for Selecting mputer Laboratory Assistant . International Conference on Cyber and IT Service Management (CITSM 2018) (pp. 1-4). Medan: IEEE.

[11] Schwab, D., Heneman III, H., \& DeCOTIIS, T. (2006). Behaviorally Anchored Rating Scales: A Review Of The Literature . Personnel Psychology, 549-562.

[12] Sevima. (2017, Juny 12). Sevima. Retrieved from Sentra Vidya Utama: https://sevima.com/pentingnya-evaluasi-kinerja-dosen/

[13] Siregar, D., Arisandi, D., Usman, A., \& Irwan, D. (2017). Research Of Simple Multi-Attribute Rating Technique For Decision Support. Journal of Phisics Conference Series, 1-6.

[14] Turban, E., Aronson, J., \& Liang, T.-P. (2005). DECISION support systems and intelligent systems. In D. Prabatini, sistem pendukung keputusan dan sistem cerdas. Yogyakarta: Andi Offset.

[15] Vance, R., Kuhnert, K., \& Farr, J. (1978). Interview judgments: Using external criteria to compare behavioral and graphic scale ratings. Organizational Behavioral and Human Performance, 279294.

[16] W.S, W. (1995). Psychology of Performance Appraisal. Jakarta: Gramedia.

[17] Wardhana, A., \& Betrianis. (2006). Supply Chain Management Performance Assessment Using Fuzzy Set Theory Method and Typical Performance Measurement Method,. Jurnal of Technology, 221-229. 